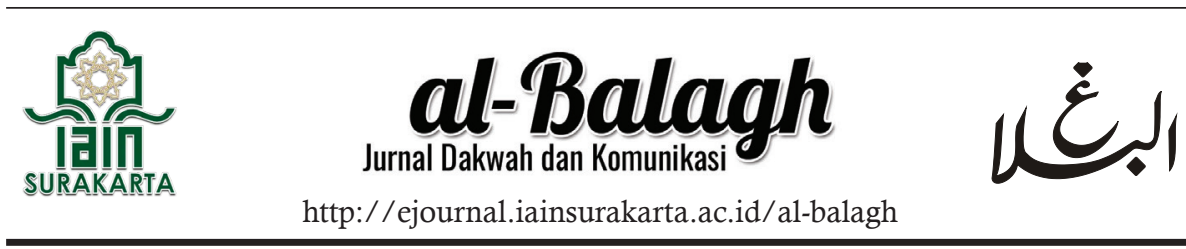

\title{
THE ROLE OF MUBALIGH AND PARENTS IN GROWING CHILDREN'S CHARACTER IN KAMPONG GAYAU SARAWAK MALAYSIA
}

\author{
Edhy Rustan*, Miftahul Jannah Akmal \\ Institut Agama Islam Negeri (IAIN) Palopo
}

\begin{tabular}{|c|c|}
\hline & Abstract \\
\hline Keywords: & This study aims to obtain an overview of how to foster children's \\
\hline $\begin{array}{l}\text { character } \\
\text { of children; } \\
\text { contributions of } \\
\text { parents; role of the } \\
\text { mubaligh }\end{array}$ & $\begin{array}{l}\text { character through the role of Islamic education from Mubaligh } \\
\text { and contributions of parents in Gayau Pantu Sri Aman } \\
\text { village, Sarawak, Malaysia. This study uses a qualitative } \\
\text { method with a case study design. The subjects of this study } \\
\text { were children aged 10-12 years old. The minority converts are } \\
\text { ten heads of families, and the preacher consists of two people }\end{array}$ \\
\hline & $\begin{array}{l}\text { who come from the community. Data were collected through } \\
\text { interviews and observations. Data analysis refers to the Milles } \\
\text { and Huberman model, namely: 1) data collection, 2) data } \\
\text { reduction, 3) data presentation, and 4) making conclusions. The } \\
\text { data validity technique used triangulation of data and sources. } \\
\text { The results showed that mubaligh and parents play a role in } \\
\text { developing children's character by applying social-oriented } \\
\text { religious learning. Religion and tolerance are the most dominant } \\
\text { characters that grow in children. }\end{array}$ \\
\hline
\end{tabular}

Correspondence:

e-mail: * edhy_rustan@iainpalopo.ac.id miftahuljannahakmal@yahoo.com 


\begin{tabular}{l}
\hline \\
\hline Kata kunci: \\
karakter anak; \\
kontribusi \\
orang tua; peran \\
mubalig
\end{tabular}
Abstrak
Penelitian ini bertujuan untuk memeroleh gambaran bagaimana menumbuhkan karakter anak melalui peran pendidikan keislaman dari Mubalig dan kontribusi orang tua di kampong Gayau Pantu Sri Aman Sarawak Malaysia. Penelitian ini mengunakan metode kualitatif dengan desain studi kasus. Subjek penelitian ini adalah anak usia 10-12 tahun. Orang tua mualaf yang minoritas berjumlah sepuluh kepala keluarga dan mubalig terdiri dari dua orang yang berasal dari kalangan masyarakat. Data dikumpulkan melalui wawancara dan observasi. Analisis data mengacu pada model Milles dan Huberman yaitu: I) pengumpulan data, 2) reduksi data, 3) penyajian data, dan 4) penarikan kesimpulan. Pengecekan kredibilitas dilakukan melalui triangulasi data dan sumber. Hasil penelitian menunjukkan mubalig maupun orang tua berperan dalam penumbuhan karakter anak melalui penerapan pembelajaran agama berwawasan kemasyarakatan. Religius dan toleransi merupakan karakter yang paling dominan tumbuh pada anak.

\section{How to cite this (APA 7th Edition):}

Rustan, E. \& Akmal, M. J. (2020). The Role Of Mubaligh And Parents In Growing Children's Character In Kampong Gayau Sarawak Malaysia. Al-Balagh: Jurnal Dakwah Dan Komunikasi, 5(2), 193-222. https://doi. org/10.22515/al-balagh.v5i2.2374

\section{INTRODUCTION}

Character as temperament (character, name) or inner nature of humans influences thoughts and actions ingrained in a person's soul. Besides, the character can also be the source of specific actions without prior thought or planning. Character consists of three interrelated and continuous parts: knowledge of morals, moral feelings, and moral behavior or actions (Lickona, 2014). A person who has a noble character will know 
his / her potential, which is marked by several values, including self-belief, patience, courage, honesty, fairness, keeping promises, being humble, and steadfast (Yusuf, 2016). Good character swill guide a person to follow good manners, norms, and social values (Mulyani, 2019; Yusuf, 2016). In the Islamic context, the character is equated with morals. Faith and rituals of worship strongly influence morals as part of the implementation of Islam.

Currently, there are many moral crises. The increasing number of child cases evidences these reports from year to year based on data from the Indonesian Child Protection Commission's commissioners quoted from Grednews.com (Shiddiq, 2020). From 2011 to 2019, the highest number of cases was in children related to law, reaching 11,492 cases. Furthermore, there were 3,323 cases of pornography and cybercrime reports, 2,820 children entangled in health problems and narcotics, and 2,156 trafficking and exploitation cases. These data indicate that there are shifts and changes in the children's character formed, which leads to deviant behavior. On the other hand, the character is essential to create a calm, peaceful, and harmonious life. Thus, character education is crucial to be instilled from an early age to strengthen children's character so that problems caused by character can be minimized.

Character education is interpreted as a deliberate effort to promote children how to behave appropriately in the family environment, society, including schools, through learning such as religion and morals (Berkowitz \& Hoppe, 2009; Roqib, 2008). Character education in Islam is also known as moral education. In Islam, character education has the same meaning as religious education based on morals. Islam sees the importance of forming a Muslim person with a noble character (akblaq alkarimah) (Mahfud \& Kertamukti, 2016; Yusuf, 2016). The hope is that the children will become the successor of a nation with good morals. Also, character education is essential in shaping personality, noble morals, controlling oneself in 
individuals from an early age to face plural society situations, and the good of themselves and society (Yusuf, 2016).

In this case, education is formal in the school environment and can also be informal (Mardliyah \& Rozi, 2019). Children's character education's success is a shared responsibility between the school, community, and parents (Kurniawan, 2019; Mulyani, 2019; Retnadi, Hayu, \& Uswatun, 2016). Many parties in society play a role in character and moral education in children; one is Mubaligh. Mubaligh is a person who gives lectures as well as being an example for children in their behavior (Fatihah, 2018; Misran, 2016; Satriah, Tajiri, \& Yuliani, 2019; Shobihah, 2014).

According to Katz \& Kahn (1966), the role's definition is an action taken by a person based on his character and position. Roles can be divided into innate roles and optional roles. In character education, parents in providing character education are an innate role as father or mother. Parental education is the first and foremost area of a child's life (Chaer, Wasim, \& Khilmiyah, 2019; Darmawati, Tolla, \& Maman, 2017; Makruf, 2017; Rozana, Wahid, \& Muali, 2017). Parents must shape their children's character and personality by instilling and developing these values (Retnadi et al., 2016; Rozana et al, 2017). Families for children are the primary source in providing a basis for socializing in society. The good and bad of children's development lies in family education, especially parents (Raganas \& Pelaez, 2016; Ulfah, Wahyuni, \& Hawasyi, 2019). In line with previous theories, Warisyah (2015) argues that parents' involvement in educating children is needed to provide encouragement and motivation and set an example for being responsible. Parents' success in fostering children's character majorly impacts the child's mindset and psychological development.

The Mubaligh is optional because the character's role is obtained when the individual becomes a preacher. However, preachers have a significant role in the growth and formation of children's character. 
For this role to run optimally, preachers should have skills in conveying religious teachings and being informative, educational, and consultative. The message told that the Mubaligh give essential information in character building. They also provide an education, which means that the preachers' message is to educate the public and children; consultative means that preachers should have the skills to help solve problems in society and children, especially those related to character morals. Besides, the roles played by preachers can also be in the form of mentoring, reforming agents, motivators, and role models for all Muslim circles in carrying out religious teachings in everyday life (Fatihah, 2018; Misran, 2016; Satriah et al., 2019; Shobihah, 2014).

To reach an in-depth analysis of the role of Mubaligh and parents concerning children's character. It is essential to conduct research. The research was conducted in Gayau Pantu Sri Aman Village, Sarawak, Malaysia. The reason for choosing this area was that Kampong Gayau was in Indonesia and Sarawak, Malaysia's border area. Kampong Gayau has minimal access, both in terms of education and access to information. However, based on preliminary observations, the Kampong Gayau children have good Islamic characters. The children still live harmoniously and mingle with each other. It is different from Aeni's (2014) opinion, which says that ten-year-olds prefer to play with friends with the same hobbies. Besides, the Kampong Gayau children's excellent character is a unique phenomenon amid widespread moral problems and children's character. Therefore, research related to the development of children's character is essential.

Previous research found that Sarawak Malaysia has a plural society phenomenon. However, in this plurality, harmony between religious communities is maintained because of the high sense of tolerance and religious understanding, which cannot be separated from Harakah Islamiah's role (HIKMAH) (Khambali, Yon, \& Sintang, 2014). 
Furthermore, researchers consider it essential to examine preachers and parents' role in fostering and developing children's character. Through the role of Islamic education, the results are expected to provide an overview of preachers and parents' role in promoting children's character to become models for children's character development in other areas.

\section{METHODS}

This research uses a qualitative approach with a case study method. The location of this research is in Kampong Gayau Pantu Sri Aman Sarawak Malaysia. The subjects of this study were children aged 10-12 years old whose parents were converts. Converts are individuals who have recently embraced Islam. The parents of converts are a minority group with ten family heads who come from the Iban tribe. Besides, this study also involved two preachers who came from the community and members of HIKMAH. The selection of subjects for children aged 10-12 years old was chosen because it is the transition age to the adolescent and adult stages. The child begins to experience rapid cognitive, moral, and social development. Besides, if they reflect on Lawrence Kohlberg's theory of moral development, children are at a pre-conventional stage, which assumes that moral reasoning is based on personal interest. It means that children's morale is still very much dependent on children's understanding and children's will. The majority of children still like the world of games. However, the children in Kampong Gayau had good character and morals. On this basis, children aged 10-12 years old were included as research subjects.

This research's object is parents' and preachers' role in fostering children's character, which is focused on religious education, worship education, and moral education. The data collection instruments used were interview and observation guidelines. The interview was a semistructured interview conducted to explore parents' and preachers' role in 198

The Role of Mubaligh and Parents In Growing Children's Character In Kampong Gayau Sarawak Malaysia Edhy Rustan, Miftahul Jannah Akmal 
developing children's character. Data analysis used four stages from the Milles and Huberman model, including data collection, data reduction, data presentation, and concluding. The data validity technique used was data and source triangulation. Data were collected by direct observation in research subjects to see parents' and preachers' role in developing children's character. On the other hand, researchers also take facilitators' role in every character education activity carried out by mubaligh.

\section{RESULTS AND DISCUSSION}

\section{The Role Of Mubaligh In Developing Children's Character}

The results of observations of children's character development by preacher SP (45 years old) and HS (39 years old) emphasized Islamic education for children, including aspects of worship, faith, and morals. Worship education teaches the practice of praying, fasting, reading the AlQur'an, and other religious teachings. Faith education teaches children to maintain and strengthen children's beliefs because Muslims in Kampong Gayau are minority groups. Meanwhile, moral education is given to children in the form of teachings about good and bad behavior to every human being and being adaptive as a child who comes from a family of converts.

The data illustrates that the preacher in Kampong Gayau has a role as a spiritual guide. The supervisor's role is to educate the family of converts and their children about the science of religion. These roles and functions significantly contribute to religious character growth as children grow up in a minority group of converts to families. The preacher's contribution is in line with Misran (2016) research, which results that preachers have a huge role in the knowledge and application of religious teachings.

Apart from providing special education for children, the preacher also realizes his preaching through tadarus with the general public and tausiab and discussion. As a preacher, the central role that is carried out in 
Kampong Gayau is in the form of religious figures which convey da'wah to minorities, both converts and the Muslim community as a whole, and this is in line with Saleh's (2012) opinion. It states that preachers are usually called preachers or preachers who have the main task of conveying Islamic teachings to humanity, both those who have believed and those who have not.

Islamic education carried out by preachers can attract children's interest in increasing Islamic knowledge, for example, about God and His creation. Children's interest in studying Islam can be seen from children who actively ask preachers about religious practice. For example, "Ustad, why do children have to follow Allah's orders, and what is the law for people who do not follow His orders?". According to Islamic teachings, this data clarifies children's desire to know the right and correct faiths and worship practices.

The results of the interview with MF (11 years old) stated that:

"My colleagues and I always go to the mosque to pray in congregation and study together with the ustad. I really like the scholars who give lessons about Islam."

In line with what was conveyed by MK (11 years old), FF (10 years old) also stated that:

"I like and often learn with ustad Hafis about Islamic teachings such as maslehat and so on."

The results of tabulating children's responses to lectures from preachers in the mosque also support children's high interest and enthusiasm in paying attention to religious teachings from preachers. Based on the tabulated responses, it was found that $60 \%$ answered often listening to lectures, $40 \%$ answered sometimes listening to lectures, and none of the children answered never.

The preacher's role as a motivator is illustrated by the high interest of diligent children in the mosque. Besides, their intensity also describes 
the child's enjoyment of studying religion with the preacher's guidance. The preacher's role as a motivator also impacts making the preacher a role model in the practice of worship and morals. The data related to this is reflected in preachers' activities considered in prayer at the mosque, such as the sunnah prayer before and after the fard prayer and tadarus after prayer. Based on interviews with RS parents (35 years old), information was obtained that the child had asked the parents about prayer. The child's question about the prayer arose because the child saw one of the preachers praying. After the hospital explained prayer that prayer is a form of worship to Allah SWT., The children began to learn to pray.

The preacher's role as a model and example for children can be viewed from an observational learning perspective. Observational learning is an individual learning process for everything from the environment by observing it and then imitating it. Therefore, observational learning gives birth to mimicking behavior, often known as modeling. This observational learning includes four processes: attention or attention, retention or representation, production, and motivation (Bandura, 1977). In the context of children in Kampong Gayau, children first pay attention to the preachers' behavior, for example, the action of praying. Preachers become objects of attention because they become teachers for children so that every preacher's behavior attracts children's attention. Next, the children tried to remember the preacher's demeanor and digest it in their cognition. At this stage, when children do not understand the behavior of preachers, they ask parents or individuals who know better, for example, asking parents about the behavior of preaching prayers. In the next stage, the children began to be motivated to produce the same behavior as the preachers' behavior. Finally, children have the motivation to behave religiously, thus forming imitative behavior, for example, imitating prayer behavior. 
Children choose great curiosity because children are in the learning process, especially learning about their environment. One that is learned by children is about morals and character. Therefore, there are stages of moral development in children formulated by Lawrence Kohlberg. Besides, children are also experiencing rapid cognitive growth, as has been formulated by Jean Piaget. According to Piaget (1952), children aged 11 years old are developing formal operational cognition. The characteristics of thinking in the proper operational stage are slowly understanding abstract things (values, norms), practicing logical thinking, and drawing conclusions from the various information. This formal operational development stage then causes the children to have a great curiosity about abstract things and try to conclude them, for example, regarding prayers and their rewards. This curiosity helps children to explore religion. When children can study religion well, it will foster a religious attitude and discipline in worship. In addition, other characteristics that can grow from a child's deep understanding of religion are tolerance, peace-loving, and democratic. This is because religions contain values, one of which is about tolerance, peace-loving, and democracy. The preachers also teach these values.

Mubalig plays a role in preparing the next generation, who will continue their duties as religious leaders in Kampong Gayau. This was confirmed by the results of an interview with SP (45 years old), who stated that:

"We focus more on emphasizing Islamic education for children with a certain schedule because children are the next generation who will advance this village based on Islam."

Mubaligh, in preparing the next generation, also instills a sense of responsibility and care for children. The character development in question is confirmed by the data from the preacher's learning observations carried out. The preacher often tells children that studying religion is compulsory, 
not only to be studied but also to be practiced and shared with others who do not understand. The message of preaching to children to practice this religion is a message of instilling responsibility in children, that everything that is understood should be practiced. The preacher's message regarding the urge to teach religion to people who do not understand and invite them is a message that focuses on caring. This responsibility and care can be extended not only to the religious field but also to various life areas.

Based on this description, it is known that the preacher in Gayau village acts as a guide, motivator, and role model for children who are minorities in that place. This role fosters children's character such as curiosity, religion, discipline, responsibility, tolerance, peace-loving, democratic, caring and responsibility. Mujiburrahman (2019) wrote that qualified educators should be taught religious education, namely individuals who are pious and have good morals and behavior. This is inseparable from the religion teacher's leading role, namely as a guide and role model.

\section{Parents' Educational Contribution In Developing Children's Character}

Parents in Kampong Gayau emphasize Islamic education for their children in practicing worship, faith, and morals. The primary practices that are taught are prayer, reading the Al-Qur'an, and fasting Ramadan. This finding is reinforced by the results of an interview with MT (40 years old), which states that:

"Sometimes studying with children about Islamic education, the most emphasized is that of praying on time, then reading the Qur'an. For teaching, they can only teach as much as they can or what is known, and the rest is given to ustad-ustad who are in the mosque and the child's formal environment. We convert still do not understand much about Islam, the barriers to work take up our time with children so that learning time with children can only be done at night, even though the 
children are still under supervision".

MM (38 years old) also stated the same thing:

"Its contribution is to provide teaching to children in the form of tadarus together, congregational prayers, providing an introduction to the fasting of Ramadan, giving guidance on Islamic teachings, not forgetting that parents also punish children for not performing prayers, tadarus, and so on."

The involvement of parents exemplifies the practice of worship and contributes to fostering religious character in children. Apart from that, parents' contribution in the form of supervision and punishment can also be seen in the interviews' results. The statement of the parent in question was confirmed by the child of AA (8 years old) in the following interview data:

"I learned tadarus together with my parents, prayed in congregation too ..., did not do the task of being whipped, ear jewing, pinching ...”.

Furthermore, the observation results show that when a child wants to break his fast for no reason, the child's parents give a warning by asking for explanations and then advising him. However, when the child still wants to break the fast, the mother scolds the child and even gives a pinch until the child cries. However, after the child was silent, the mother then apologized, then the child said:

"Forgive Aina, mother. Aina is wrong. Aina breaks the fast for no reason, even though Aina is already a big girl and can fast. “

Based on this data, it can be assumed that parents give punishment if deemed necessary and provide an example of apologizing after punishing. The parents' punishment can be considered corporal punishment because the punishment is given to one or several limbs, for example, pinching and pinching. Even though it looks successful and shapes children's behavior, 
physical punishment has negative effects, both short and long term. For example, children exhibit behavior that parents want. Still, children do not want it altogether, and the children will learn that problem solving can be done by attacking one or more limbs so that children are prone to forming aggressive behavior; punishment is not a form of discipline, but instead leads to violence; as well as negatively impacting the mental health of children (Gershoff, 2002; Marshall, 1965; Rimal \& Pokharel, 2013).

The research conducted by Ma'arif (2018) explained that punishment as one of the strategies in character education is to cultivate the character of purity to Allah. The punishment given is preventive to maintain children's behavior to continue to act according to ethical values in character education. Punishment is deemed necessary because humans have destructive instincts, so it is essential to control this behavior. On the other hand, Retnadi et al. (2016) wrote that children could be punished, primarily if they were related to religious matters. However, especially for children aged 4-6 years old, parents need to avoid punishment. This condition is caused at the age of 4-6 years old, and children tend to be obedient and cooperative so that gifts are more needed.

Based on various perspectives related to punishment, parents need to be wise. If punishment is considered an inappropriate method and causes more harmful effects, then punishment should be avoided. Although punishment is deemed necessary in character and religious education, the punishment used is educational, not destructive, and leads to violence. Moreover, punishment in religious education will be vulnerable to cause children to associate religion with violence. Thus, children will interpret religion as something scary.

Meanwhile, asking the reasons for religious violations by children and advising them is considered more effective than giving punishment. Asking the reasons for violating religious behavior in children prioritizes open communication so that children feel heard and appreciated. Besides, 
children will learn that problem solving is best done by opening up twoway communication spaces. On the other hand, parents' attitude asking for children's violations also teaches children that problem-solving is not through violent behavior.

Another role of parents is to instill discipline in children in worship. As is the case with observations, parents invite their children to pray in congregation at the mosque. In addition, they invite their children to do tadarus or recite the Qur'an together after congregational prayers at home or the mosque. Observations also show that parents ask their children to clean the neighborhood with other residents every Friday morning. Parents also teach children to mingle with other residents even though they are of different religions and teach children not to criticize other religions.

Based on these observational data, parents give lessons accompanied by examples. Parents' actions provide an example of cleaning the surrounding environment, teaching children to be tolerant, responsible, and taking social care roles in society and religion. In addition, cleaning the environment together teaches children disciplined behavior for healthy living. Giving examples to children is important because children need a real picture of each experience they get. Thus, orders alone are considered insufficient to have a practical impact on children. Therefore, parents provide examples to children while inviting them to do something, causing them to get a real picture. Thus, children do not feel heavy and have difficulty behaving according to their parents' wishes.

This study's results are in accordance with the opinion that the child's behavior can be influenced by the level of parental religiosity and a cohesive religious environment at home (Bartkowski, Xu, \& Levin, 2008). The presence of religious conditions also affects the emotional and cognitive development of children. Children's exposure to religious knowledge can teach them to think more rationally than children who are not exposed to religious knowledge (Corriveau, Chen, \& Harris, 2014). 
Parents in Kampong Gayau teach religious knowledge and teach children how to live socially interacting in society. As stated by MT (40 years old) in the following interview:

"I always take my children to the surau, hang out with the community so that they understand the meaning of life. Besides, I also enjoy giving lessons to exchange ideas or tell stories with children, spend time every night to know about their activities both at school and at home. With the discussion, the atmosphere can be more relaxed and easier for children to chat with us about activities or other things."

The same thing was said by MM (38 years old) that parents teach about social interactions in everyday life. Besides, parents also listen to children's stories about their daily lives:

"I always talk with children about various things to make it easier for us to share stories about the child's daily life and other things, this makes it easier for me to monitor my child's daily life, and by talking, the child is more open in conveying anything."

Apart from the parents' two statements, the results of the interviews with the children also obtained information that they stated that they were happy to talk with their parents. These activities are sometimes interspersed with jokes.

"Makcik and Pakcik know what I want, and I am happy when having a conversation, always give advice and tell stories about ancient times, I understand and learn a lot."

The interview results with Mr. AA (51 years old) reinforce the child's statement that children like to share stories with their parents.

"Children always share their stories with me in their spare time. It makes the children and me closer, and I can monitor their activities when they tell the stories. After that, I just give advice which is good and bad for them". 
These data show that the character development of children with parenting skills. Children trust their parents about what they want. This relationship fosters an attitude of honesty, trust, and openness in the child. Giving advice, coupled with ancient stories, instills a profound message in children. It is in accordance with the principle of memory metaphor, which says that a thousand words can be represented by one picture, a story can represent a thousand pictures. This means that character development efforts are much more effective with stories (Ready \& Burton, 2010). In addition to instilling character, children are also trained to listen to information through telling stories. Willingness and listening skills are the basis for social interaction in society.

Parents who give freedom to children to tell stories can train and get children to express their opinions. In addition, it can also introduce children to discuss. Thus, the closeness of parents with children can be well established. In the end, parents are comfortable providing education to children. Besides, parents also find it easy to supervise children because children are willing to tell stories about their daily lives without being forced.

Parents and children are a unity that cannot be separated in the family environment. Jalaluddin (2002) wrote that parent and child are bonds of the soul separated by the body but united in eternity and emotional bonds. No one can break this bond apart. The form of emotional connection between children and parents is reflected in the behavior between children and parents. The greater the emotional bond between parents and children, the closer and more significant the quality of the relationship between them. One form of closeness is the openness between parents and children.

It is also stated by Kurniawan (2015) that there must be an intense relationship with each other in a family, be it between father and mother, father and son, and between child and child. In line with this, Suciati (2016) 
states that parents should often meet and communicate with children so that these encounters can positively impact children's behavior. The involvement or contribution of parents in supporting the development of children's character is needed. As has been written by Hornby (2011), Parental involvement is defined as a form of parental participation in their children's education, processes, and experiences. Parental participation in question is such as listening to children's stories and monitoring their behavior.

The family very much determines the development of children's character. Hyoscyamina (2011) writes that parents' role in educating children has a significant influence on their development process. Likewise, Satriah et al.(2019) argue that increasing parents' parenting skills positively impact children's character. In addition, positive parental behavior can also shape positive behavior in children. So, the child's character is well developed (Hossain, Huq, Adhikari, Zai, \& Haque, 2015). There are several forms of parenting skills, such as giving examples to children and listening to children's stories.

Based on this description, it is known that parents have contributed to the development of children's character through the role of supervision, giving punishment, teaching how to socialize in the community, giving examples, and listening to children's stories. The contribution made can foster children's character, such as being religious, tolerant, disciplined, responsible, caring, and honest.

\section{Child Character Development Process}

Preachers carry out the development of children's character through Islamic education to children. The Islamic education is carried out every evening at the Al-Gayauwi mosque. While playing, the method of learning is the preacher's method in conveying the teachings of faith, morals, and worship to children. This is based on the results of an interview with MT 
(40 years old), a resident who stated that the children of Kampong Gayau were diligent in going to the mosque because the preacher taught by the playing method. This statement was reinforced by HS (39 years old):

"We teach children the play method. The learning process begins with the children neatly lining up and then given the material. The material was delivered once then the children competed to repeat the material that had been given. This method is carried out with the aim that children quickly grasp the knowledge given."

The same thing was also expressed by SP (45 years old) that the method used for the children's learning process is the learning while playing method:

"The learning process uses the learning-while-playing method, which results in making children catch learning faster."

These findings indicate that the play method's application increases children's interest and understanding of the material presented. Holis (2016) 's research results show that children are able to develop their potential and abilities optimally when the learning process uses the learning while playing method. The use of knowledge while playing methods can increase success in providing education because children will indirectly imagine themselves. In addition, the use of this method is an opportunity for children to hone their thinking and creativity. Furthermore, Rohwati (2012) wrote that learning while playing children is freer and more flexible in capturing knowledge. While playing, the learning method also causes children to feel less burdened with material that is prone to provoke boredom in learning. According to Khasanah, Prasetyo, \& Rakhmawati (2011), playing is not only a pleasure but has become a necessity for children, so it is important to be fulfilled. While playing, the learning method can encourage children to practice skills that lead to cognitive development, psychomotor development, children's language development, and physical 
development. The playing method applied by the preacher also has an impact on the development of children's character. It increases children's curiosity and fosters a democratic attitude or understanding of everyone's equal rights through preaching competitions.

In addition to playing methods, preachers also use communicative language in teaching children. The use of communicative language makes it easy for children to understand the material presented by the preacher. This can be seen from the dialogue quotations about the religious practice that reflect children's curiosity to ask questions about halal and haram laws. Children are active in asking questions and responding to the things conveyed by the preacher. The following is an excerpt from the conversation between the cleric and the children:

AA (11 years old) : "Ustad, why are Muslims forbidden to eat pork while non-Muslims are justified?"

SP (45 years old) : "Because it is regulated in Islamic law that eating pork is haram. pigs contain many worms, if we eat them will make us sick, because God loves us, eating pork is illegal."

AA (11 years old $) \quad$ : "Oh, that's right, ustad?"

SP $(45$ years old $) \quad$ : "right."

$\mathrm{N}$ (12 years old) : " "His nose is also ugly."

SP (45 years : "Yes, that's right. As well as drinking prohibited old) alcohol as it can damage the body and loss of consciousness. "

$\mathrm{N}$ (12 years old) : "I am very happy to study religion term because in Islam everything already has rules, it is not difficult for us to make our own rules because there is already the Quran and Sunnah"

The dialogue illustrates the fact that the preacher is communicative in carrying out his role. The preacher answered the questions asked by the children with answers that the children could understand. The research 
result of Ermadwicitawati, Sudiana, \& Sutama (2013) shows that language is closely related to the ability to understand children. Communicating with children needs to use the simple language according to child development and communicative. This was also expressed by Makruf (2017) that besides affecting understanding, language also impacts children's motivation in listening to the material given.

After giving material, the child is then invited by the preacher to realize the material with the help of a friend who is in front of or behind him as the application object. The interview results with SP (45 years) said that children were invited to practice the material being taught, such as prayer practices, manners, and addressing diversity. The observation reinforces that after children receive material about good and correct manners, children are immediately asked to practice it by their friends acting as parents and then talking to them based on excellent and accurate manners that have been taught. This practice method is called role play. This method causes children to have the motivation to attend religious education. Like the research results Samsibar \& Naro (2018) and Saptono (2010), learning methods with role play can arouse children's motivation and improve children's learning outcomes.

The results of the role-play method can be seen from the behavior of children towards their parents. For example, based on observations, when a child sees a parent needing help, the child then offers to help and immediately helps. Besides, according to FF (11 years old), it is imperative to help parents.

“Helping the parents' work is mandatory and cannot be denied. In fact, by just saying 'ah', then the child will sin."

Parents also practice methods of practice. However, before teaching children, parents first understand Islam and then transfer the child's knowledge. One example is that parents introduce Ramadan fasting to 
their children and explain its benefits. Then, parents invite children to practice fasting.

This practice and habituation method is in line with that proposed by Fatiha (2018), one of the principles in developing children's character is exemplary practice and habituation. The same thing was expressed by Yusuf (2016). Character learning can be done through habituation in the form of speech in learning prayer sentences and habituation in the form of behavior, such as prayer and fasting activities. The habits that are instilled from childhood will develop into characters when they grow up. They will do the things that have been taught automatically, with their awareness without others' orders or coercion (Mulyani, 2019).

Based on these data, it can be understood that the character-building by the preacher uses the play method, the use of communicative language, and practices the material that has been taught directly. Meanwhile, parents foster children's character by deepening knowledge first and then teaching it to children. After that, parents invite children to practice it through habituation. In addition, parents also punish children when children violate religious rules and behave, deviating from good character. Children's character education's success is a shared responsibility between the school, community, and parents (Kurniawan, 2019; Mulyani, 2019; Retnadi et al., 2016).

Preachers and parents carry out efforts to develop children's character through religious learning with social insight. The use of communicative language (in this case, Malay) and the learning process through practices associated with everyday life in society are examples of the implementation of community-based learning. This method is a learning method that uses various potentials/resources in the community to develop their potential and practice it in everyday life (Hadi, 2019). An example of community-based religious learning is that children are invited 
to interact socially with people of different religions. In addition, parents invite their children to work together with other communities to foster a character of togetherness and care.

The preacher's religious education process is different from mono religious education in the teaching process in general in formal schools. Monoreligious education has a weakness; namely, it does not recognize the plurality of religions as expressed Yusuf (2020). Preachers and parents carry out efforts to develop children's characters through religious learning with social insight. The use of communicative language (in this case, Malay) and the learning process through practices associated with everyday life in society are examples of the implementation of community-based learning. This method is a learning method that uses various potentials/resources in the community so that students are able to develop their potential and can practice it in everyday life.

\section{Barriers To Child Character Development}

In this process, it is not uncommon for preachers and parents to experience obstacles. SF (45 years old) revealed various obstacles he encountered, example children were still difficult to manage, and sometimes children still had difficulty understanding the explanation from the preacher. However, these obstacles are a modality for preachers and parents in improving learning methods. Apart from barriers that come from children, there are also barriers from the parents' personality. As expressed by parents, parents are constrained by a lack of understanding of Islam as a convert (MM, 38 years old). In addition, parents' limited time due to their focus on work to fulfill family income is also an obstacle to assisting the child's learning process (MT, 40 years old). However, they still tried to study religion and teach it to their children. This can be seen from the observation that the community asked to form a special assembly and understand Islamic teachings, such as the Koran, prayer, dhikr, azan, and other knowledge. 
This phenomenon indicates that parents in Kampong Gayau have the enthusiasm to explore religious knowledge as provisions for themselves and their children. Research result Makruf (2017) stated that parents and teachers should have the same understanding and vision in building children's character. Character education is not only the responsibility of one party but is a joint responsibility of parents, schools, and the community, especially preachers (Kurniawan, 2019; Mulyani, 2019; Retnadi et al., 2016). stated that parents and teachers should have the same understanding and vision in building children's character. Character education is not only the responsibility of one party but is a joint responsibility of parents, schools, and the community, especially preachers (Mujiburrahman, 2019). Besides, Rozana et al. (2017) argue that parents should recognize the characteristics and needs of children because these two things greatly influence the parenting style and educational methods provided. If the parenting style and educational practices are not in accordance with the child's characteristics or needs, it will trigger conflict between parents and children. Thus, it can have a negative impact on children. The most appropriate parenting patterns and educational methods are authoritative patterns. Authoritative patterns are patterns of care and education carried out by parents by providing good direction and assistance to children to not appear to be pressing (Baumrind, 1966, 1991).

\section{CONCLUSION AND SUGGESTION}

\section{Conclusion}

Mubaligh in Kampong Gayau Pantu Sri Aman Sarawak Malaysia provides religious education, faith, and morals for children of minority groups, converts, and other Muslim communities. The role played by the preacher is as a guide, motivator, and role model. Mubaligh and parents carry out community-based religious learning according to the needs and age of the child. Parents' role is to explore religious knowledge 
first, then teach children through practice, habituation, and punishment. Several characters begin to appear, including religious attitudes, discipline, tolerance, responsibility, curiosity, caring, peace-loving, and honesty. The dominant characters are religious and tolerant.

\section{Suggestion}

Suggestion for parents in Kampong Gayau is to improve time management to have sufficient time to accompany the children's learning process. In addition, parents should not give punishment to children and prioritize open communication for problem-solving. Punishment has a negative impact that outweighs the positive effect. Suggestions for preachers are to use more varied learning methods and be adapted to the conditions of children's development, both cognitive, affective, and moral development of children. Suggestions for future researchers are to use another approach to find out the level of each character that is formed.

\section{REFERENCES}

Aeni, N. A. (2014). Pendidikan Karakter Untuk Siswa SD Dalam Perspektif Islam. Mimbar Sekolah Dasar, 1(1), 50-58. https://doi. org/10.17509/mimbar-sd.v1i1.863

Bandura, A. (1977). Social Learning Theory. New York, USA: General Learning Cooperation.

Bartkowski, J. P., Xu, X., \& Levin, M. L. (2008). Religion and child development: Evidence from the Early Childhood Longitudinal Study. Social Science Research, 37(1), 18-36. https://doi. org/10.1016/j.ssresearch.2007.02.001

Baumrind, D. (1966). Effects Of Authoritative Parental Control On Child Behavior. Child Development, 37(4), 887-907. https://doi. org/10.2307/1126611 
Baumrind, D. (1991). Parenting Styles And Adolescent Development. In J. Brooks-Gunn, R. Lerner, \& A. C. Petersen (Eds.), The Encyclopedia of Adolescent (Vol. 2). New York, USA: Garland.

Berkowitz, M. W., \& Hoppe, M. A. (2009). Character Education And Gifted Children. High Ability Studies, 20(2), 131-142. https://doi. org/10.1080/13598130903358493

Chaer, M. T., Wasim, A. T., \& Khilmiyah, A. (2019). Character Education For Single Parent Children In The Quran. Proceedings Of The 1st Annual Internatioal Conference On Social Sciences And Humanities (AICOSH 2019), 36-39. https://doi.org/10.2991/aicosh-19.2019.7

Corriveau, K. H., Chen, E. E., \& Harris, P. L. (2014). Judgments About Fact And Fiction By Children From Religious And Nonreligious Backgrounds. Cognitive Science, 39(2), 353-382. https://doi. org/10.1111/cogs.12138

Darmawati, D., Tolla, A., \& Maman, M. (2017). The Study Of Parents' Words, Behavior And Attitude As The Means To Build The Children's Character In Bulukumba Regency. Journal of Language Teaching and Research, 8(4), 750-755. https://doi.org/10.17507/ jltr.0804.14

Ermadwicitawati, N. M., Sudiana, I. N., \& Sutama, I. M. (2013). Pengembangan Materi Ajar cerita Anak yang Mengandung Pendidikan Karakter Pada Pembelajaran Membaca Cerita Anak SMP Kelas VII di Singaraja. Jurnal Pendidikan Dan Pembelajaran Bahasa Indonesia, 2, 1-11.

Fatihah, I. (2018). Peran Nahdatul Ulama (NU) Dalam Bidang Pendidikan Karakter. Al-Tarbawi Al-Haditsab: Jurnal Pendidikan Agama Islam, 3(2), 1-18. https://doi.org/10.24235/tarbawi.v3i2.3116

Gershoff, E. T. (2002). Corporal Punishment By Parents And Associated Child Behaviors And Experiences: A Meta-Analytic And Theoretical Review. Psychological Bulletin, 128(4), 539-579. https:/ / doi.org/10.1037//0033-2909.128.4.539

Hadi, A. (2019). Membentuk Anak Berkepribadian Handal Melalui Pendidikan Kemasyarakatan. Jurnal Kariman, 6(2), 281-288.

Holis, A. (2016). Belajar Melalui Bermain Untuk Pengembangan Kreativitas Dan Kognitif Anak Usia Dini. Jurnal Pendidikan Universitas Garut, 9(1), 23-37. 
Hornby, G. (2011). Parental Involvement in Childhood Education: Building Effective School-Family Partnerships. New York, United States: Springer.

Hossain, S. M., Huq, S., Adhikari, B., Zai, S. Z. E., \& Haque, S. M. T. (2015). Parenting Skills and Child Behavior: A Cross-Sectional Study in Some Selected Areas of Nepal. Southeast Asia Journal Of Public Health, 5(1), 44-48. https://doi.org/10.3329/seajph. v5i1.24851

Hyoscyamina, D. E. (2011). Peran Keluarga Dalam Membangun Karakter Anak. Jurnal Psikologi, 10(2), 144-152. https://doi.org/10.14710/ jpu.10.2.144-152

Jalaluddin. (2002). Psikologi Agama. Jakarta: Rajagrafindo Persada.

Katz, D., \& Kahn, R. L. (1966). The Social Psychology of Organizations. New York, United States: Wiley.

Khambali, K. M., Yon, W. A. W., \& Sintang, S. (2014). Toleransi Dan Pluralisme Menurut Pengalaman Masyarakat Bidayuh. Jurnal Usuluddin, 40, 99-134.

Khasanah, I., Prasetyo, A., \& Rakhmawati, E. (2011). Permainan Tradisional Sebagai Media Stimulasi Aspek Perkembangan Anak Usia Dini. PAUDLA: Jurnal Penelitian Dalam Bidang Pendidikan Anak Usia Dini, 1(1), 91-105. https://doi.org/10.26877/paudia.v1i1.261

Kurniawan, M. I. (2015). Tri Pusat Pendidikan Sebagai Sarana Pendidikan Karakter Anak Sekolah Dasar. PEDAGOGLA: Jurnal Pendidikan, 4(1), 41-49. https://doi.org/10.21070/pedagogia.v4i1.71

Kurniawan, S. (2019). Pantang Larang Bermain Waktu Magrib (Kajian Living Hadis Tradisi Masyarakat Melayu Sambas). Jurnal Living Hadis, 4(1), 1-26. https:/ / doi.org/10.14421/livinghadis.2019.1629

Lickona, T. (2014). Pendidikan Karakter; Mendidik Untuk Membentuk Karakter. Bandung: Nusa Media.

Ma`arif, M. A. (2018). Analisis Strategi Pendidikan Karakter Melalui Hukuman Preventif. Ta'allum: Jurnal Pendidikan Islam, 6(1), 31-56. https://doi.org/10.21274/taalum.2018.6.1.31-56

Mahfud, M., \& Kertamukti, R. (2016). Desain Komunikasi Dakwah Visual Animasi 2D Untuk Anak (Studi Deskriptif Kualitatif Di SDN Monggang Pendowoharjo Sewon Bantul). Profetik Jurnal Komunikasi, 9(2), 45-64. 
Makruf, S. A. (2017). Strategi Dan Metode Pendidikan Anak Dalam Membangun Generasi Berkarakter Islami. AJIE - Asian Journal of Innovation and Entrepreneurship, 2(3), 364-369.

Mardliyah, A. A., \& Rozi, S. (2019). Karakter Anak Muslim Moderat: Deskripsi, Ciri-Ciri dan Pengembangannya di Lembaga Pendidikan Anak Usia Dini. TARBIYA ISLAMLA: Jurnal Pendidikan Dan Keislaman, 8(2), 231-246. https://doi.org/10.36815/tarbiya. v8i2.476

Marshall, H. H. (1965). The Effect Of Punishment On Children: A Review Of The Literature And A Suggested Hypothesis. The Journal of Genetic Psychology: Research and Theory on Human Development, 106(1), 23-33. https://doi.org/10.1080/00221325.1965.10533077

Misran. (2016). Peran Mubaligh Dalam Penerapan Ajaran Islam Pada Remaja Masjid Al-Khaerat Desa Teteasa Kecamatan Angata Kabupaten Konawe Selatan, Skripsi (Unpublished). Kendari: IAIN Kendari.

Mujiburrahman, M. (2019). State And Religion In Aceh: The Competences Of Religious Education Teachers (Referring To ACT 14, 2005). AlAlbab, 8(1), 83-100. https://doi.org/10.24260/alalbab.v8i1.1330

Mulyani, S. (2019). Peran Ibu Dalam Pendidikan Karakter Anak Menurut Pandangan Islam. An-Nisa, 11(2), 511-525. https://doi. org/10.30863/annisa.v11i2.336

Piaget, J. (1952). The Origin Of Intelligence In Children. New York, United States: Oxford University Press.

Raganas, N. S., \& Pelaez, C. (2016). Parents' Cognitive And Affective Interactions In The Character Development And Aspirations Of Children Engaged In Labor In Butuan City, Philippines. Annals Of Studies In Science And Humanities, 2(1), 26-35.

Ready, R., \& Burton, K. (2010). Neuro-Linguistic Programming For Dummies (2nd Ed.). Hoboken, New Jersey, United States: John Wiley \& Sons.

Retnadi, W., Hayu, R., \& Uswatun, D. A. (2016). Integration Of School And Family As Min Character Education In Early Childhood. International Seminar on Education: Education Trends for Future Society, (August), 45-51. 
Rimal, H. S., \& Pokharel, A. (2013). Corporal Punishment And Its Effects In Children. Journal of Kathmandu Medical College, 2(3), 156-161. https://doi.org/10.3126/jkmc.v2i3.9968

Rohwati, M. (2012). Penggunaan Education Game Untuk Meningkatkan Hasil Belajar IPA Biologi Konsep Klasifikasi Makhluk Hidup. Jurnal Pendidikan IPA Indonesia, 1(1), 75-81. https://doi.org/10.15294/ jpii.v1i1.2017

Roqib, M. (2008). Pendidikan Seks Pada Anak Usia Dini. INSANIA: Jurnal Pemikiran Alternatif Pendidikan, 13(2), 271-286. https://doi. org/10.24090/insania.v13i2.298

Rozana, A. A., Wahid, A. H., \& Muali, C. (2017). Smart Parenting Demokratis Dalam Membangun Karakter Anak. Al-Athfal: Jurnal Pendidikan Anak, 4(1), 1-16. https://doi.org/10.14421/alathfal.2018.41-01

Saleh, A. (2012). Peran Muballigh Dalam Pembinaan Remaja. Jurnal Dakwah Tabligh, 13(2), 227-234. https://doi.org/10.24252/jdt. v13i2.306

Samsibar, S., \& Naro, W. (2018). The Effectiveness Of Role Play Method Toward Students' Motivation In English Conversation. ETERNAL (English, Teaching, Learning and Research Journal), 4(1), 107-116. https://doi.org/10.24252/eternal.v41.2018.a8

Saptono, L. (2010). The Implementation Of Role-Playing Model In Principles Of Finance Accounting Learning To Improve Students Enjoyment And Students Test Scores. Finance \& Accounting Journal, 12(2), 71-81. https://doi.org/10.9744/jak.12.2.pp.71-81

Satriah, L., Tajiri, H., \& Yuliani. (2019). Parenting Skills Untuk Membangun Karakter Anak: Aplikasi Dakwah Melalui Bimbingan Kelompok. Bandung: Prodi Manajemen Dakwah Universitas Islam Negeri Sunan Gunung Djati Bandung.

Shiddiq, M. (2020). Kasus Anak Berhadapan dengan Hukum Terbanyak Dilaporkan ke KPAI. Retrieved February 12, 2020, from gresnews.com, wesbite https://www.gresnews.com/ berita/isu_terkini/117602-kasus-anak-berhadapan-denganhukum-terbanyak-dilaporkan-ke-kpai/\#: : text=Komisi\%20 Perlindungan $\% 20$ Anak\%20Indonesia $\% 20$ (KPAI, berhadapan $\% 20$ dengan $\% 20$ hukum $\% 20(\mathrm{ABH}) \cdot$. \&text $=$ Menurut $\% 20$ 
Komisioner\%20KPAI\%20Retno\%20Listyarti,sejak\%202011\%20 sampai\%20tahun\%20lalu.

Shobihah, I. F. (2014). Kebersyukuran (Upaya Membangaun Karakter Bangsa Melalui Figur Ulama). Jurnal Dakwah: Media Komunikasi Dan Dakwah, 15(2), 383-406. https://doi.org/10.14421/jd.2014.15208

Suciati. (2016). Psikologi Komunikasi: Sebuah Tinjauan Teoritis Dan Perspektif Islam. Yogyakarta: Buku Litera.

Ulfah, S. M., Wahyuni, S. A., \& Hawasyi, L. H. (2019). Nilai Tanggung Jawab Sebagai Karakter Anak Negeri Melayu Jambi Yang Bersendikan Syara' Dan Syara' Bensendikan Kitabullah. Smart Kids: Jurnal Pendidikan Isam Anak Usia Dini, 1(1), 1-8.

Warisyah, Y. (2015). Pentingnya "Pendampingan Dialogis" Orang Tua Dalam Penggunaan Gadget Pada Anak Usia Dini. Seminar Nasional Pendidikan, 130-138.

Yusuf, M. (2020). Why Indonesia Prefers A Mono-Religious Education Model? A Durkheimian Perspective. Al-Albab, 9(1), 37-54. https://doi.org/10.24260/alalbab.v9i1.1555

Yusuf, M. (2016). Pendidikan Karakter Pada Anak Usia Dini: Perspektif Pendidikan Islam. Elementary: Jurnal Ilmiah Pendidikan Dasar, 2(1), 13-18. 
Al-Balagh: Jurnal Dakwah dan Komunikasi,

Vol. 5, No. 2, July - December 2020, pp. 193 - 222, DOI: https:/ / doi.org/10.22515/al-balagh.v5i2.2374

ISSN: 2527-5704 (P) ISSN: 2527-5682 (E) 